
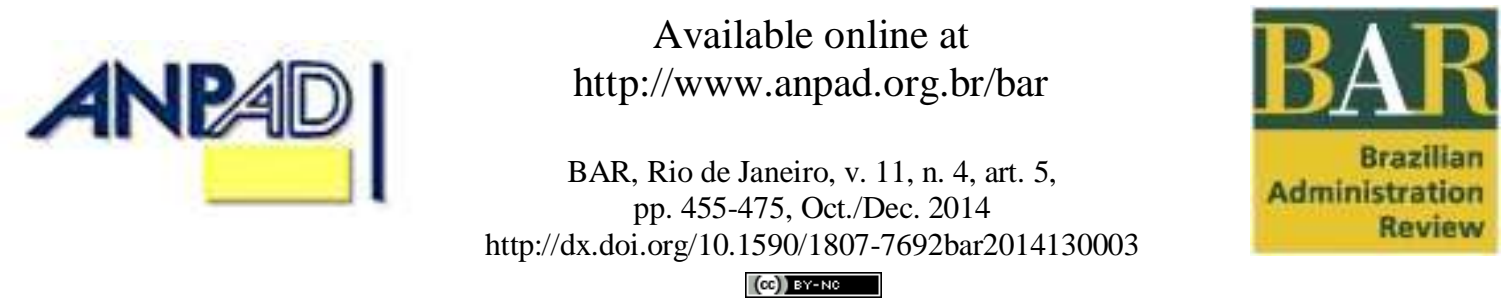

\title{
Heterogeneity of Isomorphic Pressures: Intertwining the Resource-Based View and the Neoinstitutional Approach
}

Silvio Popadiuk

E-mail address: spopadiuk@gmail.com

Universidade Presbiteriana Mackenzie - CCSA Rua da Consolação, 896, Prédio 29 - PPI, 01302-907, São Paulo, SP, Brazil.

Edward Rivera Rivera

E-mail address: riverarivera@uol.com.br

Universidade Presbiteriana Mackenzie - NEVAL Rua da Consolação, 896, 01302-907, São Paulo, SP, Brazil.

Walter Bataglia

E-mail address: batagliaw@gmail.com Universidade Presbiteriana Mackenzie - CCSA Rua da Consolação, 896, Prédio 29 - PPI, 01302-907, São Paulo, SP, Brazil.

Received 22 July 2013; received in revised form 15 August 2014 (this paper has been with the authors for three revisions); accepted 20 August 2014; published online ${ }^{\text {st }}$ October 2014. 


\begin{abstract}
The purpose of this research is to establish a conceptual framework that contributes to explaining sustained competitive advantage, forming an analytical framework that brings the resource-based view and organizational analysis' neoinstitutional approaches closer together. A detailed epistemological articulation has been undertaken to advance the understanding of strategy and competitive advantage in organizations, aggregating contribution to the literature with the proposal of a theoretical model that steadily articulates elements from organizational institutionalism and the resource-based view. Hence, the major contribution is to associate the resource-based view and organizational analysis' neoinstitutional theory as a means to reformulate the notion of institutional isomorphism, and have a potential new explanation for organizational diversity and the existence of organizations that are more capable of generating (or maximize) value than others. In its formulation, the similarity among organizations in their fields provides the baseline for organizational performance. Thus, it is from this baseline level that organizations would then be able to differentiate themselves and generate sustainable competitive advantage through active and selective response to different institutional pressures.
\end{abstract}

Key words: isomorphism; resources; diversity; heterogeneity; competitive advantage. 


\section{Introduction}

The purpose of our paper is to present the foundations of organizational analysis' neoinstitutionalism (Nee, 2005), highlighting the concepts of legitimacy and isomorphism, as combined with elements of the resource-based view to support the idea of sustained organizational strategy. Based on Lippman and Rumelt (1982) and Barney (1991), an organization possesses a competitive advantage when it implements a value-creating strategy not implemented by current or potential competitors; additionally, an organization maintains a sustained competitive advantage when such competitive advantage continues to exist after efforts to duplicate that advantage have ceased.

Economic theory argues that, in the absence of market imperfections, abnormal economic rents will be diluted as rivals and new entrants join the industry. Resource-based view, the dominant paradigm in strategic research, advances in the sense that organizations can obtain sustained abnormal returns if they own superior resources and are protected by mechanisms that prevent their diffusion throughout the industry. Hence, the concept of competitive advantage can be related directly to the notion of profits in excess of the opportunity cost of capital, and a persistently higher rate of return than competitors. An organization holds a sustained competitive advantage when the value creating strategy is not implemented by current or potential competitors and its benefits cannot be duplicated by others (Barney, 1986, 1991; Hamel \& Prahalad, 1994; Lippman \& Rumelt, 1982; Penrose, 1959; Peteraf, 1993; Rumelt, 1984; Wernerfelt, 1984).

On the other hand, neoinstitutionalism aims to develop a sociological view of institutions. This theory describes the way they interact and how they affect society. It provides a manner for observing institutions outside traditional economic views by explaining why so many businesses end up having similar organizational structures in spite of evolving in different ways. Meyer and Rowan (1977) and DiMaggio and Powell (1991) examine that organizations incorporate socially-rationalized procedures to achieve legitimacy, regardless of the effectiveness of those practices. Nonetheless, while neoinstitutionalism explains organizations' survival through continuous adoption of legitimized structures, it has failed to specify how competitive advantage in the form of abnormal returns can be obtained by an organization.

The association of the resource-based view and neoinstitutional theory is developed in this work as a means to establish the potential of a new explanation towards organizational diversity and the existence of organizations that are more capable of generating and maintaining (or maximizing) value than others. The similarities of organizations in the institutional field only provide the baseline for organizational performance. Thus, it would be from this underlying level that organizations would be need to differentiate themselves and generate sustainable competitive advantage through active and selective response to different institutional pressures.

There are several explanations for organizational heterogeneity in the different theoretical approaches on organizations (Table 1). All have their basis in the systemic movement. The design of organizations as open systems considers organizations and their external environments as parts of a larger system that interacts continuously. The organization exchanges resources with the environment, ensuring its survival, and changes to adapt to environmental contingencies that give access to these resources. 
Table 1

\section{The Main Organizational Theories about Organizational Heterogeneity}

\begin{tabular}{ll}
\hline Theory & Main ideas \\
\hline $\begin{array}{l}\text { Structural } \\
\text { Contingency }\end{array}$ & $\begin{array}{l}\text { The organization exchanges resources with the environment, ensuring its survival, and } \\
\text { changes through strategic decision making to adapt to environmental contingencies that } \\
\text { give access to these resources (Burns \& Stalker, 1961). }\end{array}$
\end{tabular}

Neoclassical

Neoclassical theory provides a new dimension to management, which engages with the internal and external environments through strategic planning; i.e., the process of organizational alignment with the external environment from its analysis and development of strategies for action, adapting the organization to the environment (Caves \& Porter, 1977).

Organizational Ecology

Organizational ecology (Hannan \& Freeman, 1977) focuses explanation on the idea that the diversity of organizational forms is isomorphic to the diversity of existing environmental niches. However, it adds to this idea the theory of competing populations; i.e., groups of companies with the same organizational form that compete for available resources in the niche. Because resources are finite and the competition is not restricted, the population best adapted to their characteristics survives in each niche. This idea became known as competitive isomorphism. Inside these populations, organizations compete for the available resources.

Resource Resource dependent theory focuses on the view that managers seek to understand the Dependency organizational environment and make strategic decisions designed to control the resources that companies need through political action on other environmental actors, thus differentiating their organizations (Pfeffer \& Salancik, 1978).

Structural It is for the organization to optimize the choice of structure-delineating and situational Dependency factors related, respectively, to the organization itself and its external environment, seeking settings as congruent as possible. Thus, organizations in the same industry can have different structural configurations depending on their preferences and the choice of segment in which they act (Mintzberg, 2003).

Resource and Capability Based Approaches

Intra-industry heterogeneity due to creative resource-arrangement employment generates differences and opportunities in financial performance. Competitive advantage is kept through the maintenance of resources position barriers (Wernerfelt, 1984).

This investigation follows a research tradition focused on the conversation of organizational institutionalism with other economic approaches in the analysis of organizational practices and strategies (e.g., Beckert, 2010a; Conney, 2007; Delbridge \& Edwards, 2013; Feldman \& Pentland, 2003; Holmes, Miller, Hitt, \& Salmador, 2013; Queiroz, Vasconcelos, \& Goldszmidt, 2007). Beckert (2010a) offers a discussion of the interrelationships between Economic Sociology's networks (Granovetter, 1985) and institutional and cognitive levels and their role in the change of market fields. Conney's (2007) work, based on Giddens' (1984) Structuration Theory and on the theoretical support of the New Institutional Economics (North, 1992), sought to analyze the process of institutionalization from an agency perspective. Delbridge and Edwards (2013) applied critical realism (Azevedo, 2002) to better understand the interdependencies between actions, contexts and institutional logics. Feldman and Pentland (2003) used Giddens' and Bourdie's contributions to propose a reviewed ontology of Evolutionary Economics' organizational routine construct (Nelson \& Winter, 1982) based on the interaction between its performative (concerning the agency) and ostensive (relating to institutional structure) dimensions. Holmes, Miller, Hitt and Salmador (2013) examined the effects of informal and formal institutions on countries' inward foreign direct investment. The conclusions suggest that a country's informal institutions shape its formal institutions, which in turn, affect foreign managers' cognitive frames, which seek to invest in countries with institutional environments that allow their firms to leverage specific advantages. Seeking to assess legitimacy and strategic resource, Queiroz, 
Vasconcelos and Goldszmidt (2007) observed that institutional entrepreneurship involves ambiguity and contradiction and, although it aims for differentiation, involves isomorphism.

This investigation is able to aggregate relevant contribution through the purpose of a theoretical model that steadily articulates meaningful elements from the resource based view and neoinstitutionalism for this understanding. Even though isomorphism is a fundamental concept in the construction of the proposed model, its focus lies on explaining the heterogeneity of isomorphic pressures. Thus, we present the fundamentals of neoinstitutionalism, comprising concepts of legitimacy and isomorphism, to compose a perspective of the institutional environment complementing the original explanation of the resource-based view, to lay the foundations of sustainable organizational strategy.

Along these lines, this work reassesses the idea of analyzing the organization as a passive actor driven by environmental changes, by identifying its sharing of the process. Two fundamental advances are proposed: (a) organizations that have the ability to define rationalized myths of their organizational fields have increased competitive advantage; (b) development of a relevant conversation between neoinstitutionalism and resource-based theory, rather than just having the latter subsumed into the former, suggesting the prospect of raising the resource-based theory to the societal and organizational field levels. Therefore, this investigation revises and provides an alternative notion of institutional isomorphism as well as the exploration of the theme regarding organizational responses. Hence, this investigation is aligned with contemporary theoretical issues, given, particularly, the growing interest in exploring possible points of convergence among the institutional, cognitive and agency levels (Beckert, 2010a, 2010b; Campbell, 2004; Streeck \& Thellen, 2005).

As these sociologic and economic approaches are conjugated, epistemological issues arise. The sociological basis of neoinstitutionalism embodies a duality of institutional structure and agency (Berger \& Luckman, 1967). The first embodies the typification of habitual actions, values and rules sustained by a social group (institutional structure) while the second consists of its member's actual actions at specific times, in specific places (agency). The resource based view goes beyond an analytical character and does not abandon the agency prescriptive focus on the economic organizational relationship, adopting formalistic and timeless elements. Concerning the delimitation of this theoretical research, the approach undertaken is centered on the agency and its relation with the institutional level, adopting a primarily analytical focus, as it explains why certain organizations are more successful than others when selecting an array of resources for competing in a market.

\section{Resource-based View Framework: The Idiosyncratic Employment of Resources}

Penrose (1959), Wernerfelt (1984), Barney $(1986,1991)$ and Peteraf (1993) are widely known in strategy literature. The resource-based view characterizes the dominant paradigm in organizational strategy where resources are key performance-determinants. Important concepts from Penrose (1959) include organizational analysis as a collection of resources; the optimization in the growth path of a particular organization, combining internal and external resources; the process of organizational growth depends on characteristics concerning management as well as their experience and ability to learn. Penrose (1959) examines that the services that a given set of resources provides will be different depending on their idiosyncratic implementation. Thus, intra-industry heterogeneity due to creative resources employment generates differences and opportunities in financial performance.

Barney $(1986,1991)$ defines resources as tangible and intangible assets that firms control and can use for strategy conception and implementation. According to Wernerfelt (1984) resources can be seen as a strength or weakness of a particular organization. Organizational resources are classified into three categories: physical capital resources, such as greenfields and equipment, geographic location, capital and access to raw materials; human capital resources, such as training, experience, judgmental capacity, intelligence, social relationships and managers' and employees' insights; organizational capital resources, including infrastructure, capabilities, organizational processes, decision-making and 
planning systems, control, coordination systems, company attributes, information, knowledge, in-house technology, hiring policies, organizational structure, business relations (partnership, government, community, distribution, customer, financial, industrial and supplier relations), reputation, leadership, prestige, and informal relationships among groups within and between the organization and its environment.

Differently from the traditional neoclassical view, Wernerfelt (1984) examines the organization as a set of resources, where competitive advantage is generated through the maintenance of resource position barriers. Organizational resources are considered heterogeneous as in Penrose (1959), while barriers to resources are partially similar to entry barriers, since an entry barrier without a resource barrier places the organization in a vulnerable position to new entrants while a resource barrier is valuable only when it translates into an entry barrier in at least one market.

Based on Porter's (1980) five forces, originally designed for product analysis, Wernertfelt (1984) assesses that for resource barriers to generate profitable opportunities, there must be no supplier bargaining power - if a monopolistic group controls resources, returns will decrease to the users of that resource; no buyer bargaining power - once a given resource is sold in monopsony markets, the owner will earn lower profits; no threat of substitute resources - whose availability will reduce returns for the holder of a given resource; no threat of new entrants - discouraged through first mover advantage, as well as resource barriers, and rivalry among existing competitors - limited by the development of industry barriers to inimitable resources. Nevertheless, Barney (1991, p. 100) criticizes the "five forces model" approach as eliminating heterogeneity and immobility as sources of competitive advantage for two reasons: (a) the assumption that organizations within an industry are identical in terms of strategically-relevant resources controlled and strategies pursued; (b) the heterogeneity developed in an industry will be very short lived, as resources are considered highly mobile.

An organization owns competitive advantage when current and potential competitors are unfit to simultaneously establish or duplicate the benefits of this strategy. Not all organizational resources generate sustainable competitive advantage. To induce competitive advantage, a resource must be VRIN: valuable to explore opportunities and neutralize threats in the organizational environment; rare among the current and potential competition; inimitable or imperfectly replicable; and nonsubstitutable given the unavailability of a strategic substitute resource. A resource can be imperfectly replicable due to: capability to possess a resource because it is dependent on unique historical conditions (path dependency); ambiguous relationship of causality between resources and competitive advantage (causal ambiguity); employment of a resource that is socially complex, such as culture or reputation towards suppliers and customers (social complexity) (Barney, 1991).

Heterogeneity may reflect the presence of superior productive factors available in limited supply. Factors can be fixed or, more frequently, quasi-fixed in the sense that their supply cannot be expanded quickly. They are scarce vis-à-vis the demand. Imperfect mobility concerns idiosyncratic resources with no use outside a given organization or, alternatively, tradable resources that present more value inside than outside an underlying organization. Ex-ante limits to competition means economic performance depends on returns generated and the cost of implementing a strategy. Ex-post limits to competition address the preservation of diversity to keep sustainable competitive advantage over time, since strategists are primarily interested in long-term profits (Barney, 1986; Peteraf, 1993). Subsequent to the position to earn higher profits, there must be forces that limit competition for these profits, given that competition might dissipate gains through increased supply of scarce resources.

High prices induce less efficient organizations to enter an industry as long as prices exceed marginal cost (MC). In equilibrium, demand and supply are equal, occurring the breakeven in high-cost organizations $(\mathrm{P}=\mathrm{MC})$, while low-cost organizations obtain extraordinary profits in the form of rents for their scarce resources $(\mathrm{P}>\mathrm{MC})$. A fundamental element is that superior resources remain limited in supply and, while most resources can be sold in imperfect markets of strategic factors, some assets need to be accumulated internally (i.e. relationships between a company and its suppliers and customers), based on the premise that marketable resources, due to inherent mobility, do not constitute sustained competitive advantage (Basso, Meirelles, \& Pace, 2005; Dierickx \& Cool, 1989; Ginsberg, 1990; 
Peteraf, 1993). The resource-based assumption that strategic resources are created by consistent policies and accumulated internally implies the role of institutionalization towards organizational heterogeneity from intangible and non-tradable resources.

\section{Neoinstitutional Framework: Corporate Isomorphism and Legitimacy}

Similar to the resource based view, neoinstitutional theory also adopts an open system perspective, which means organizations undergo strong environmental influences. Hence, not only do forces based on competition and efficiency act upon the organization, but socially constructed beliefs and systems of rules also exert considerable control over organizations. Meyer and Rowan (1977), DiMaggio and Powell (1983) and Scott (2001) are among its seminal authors. The neoinstitutionalism considers myths and routines and conformity confers legitimacy to organizations. Institutions are conceived of as social constructions governed by rules, and institutional systems of interrelated formal and informal rules are construed as facilitating, motivating and governing economic behavior (Berger \& Luckmann, 1967; DiMaggio \& Powell, 1991; Meyer \& Rowan, 1977; Nee, 2005; Scott, 2001).

Modern organizational theory considers a world of diverse and different organizations and seeks to explain variations in organizational structures and behavior. Hence, it is of interest to investigate the reasons why considerable homogeneity exists among organizations, considering that, in the early stages of their life cycles, industries display considerable diversity in their organizations' forms and practices. However, as the industry becomes well established, a trend exists toward homogenization. Meyer and Rowan (1977) analyze that organizations incorporate socially rationalized structures (procedures, products, services, techniques, policies and programs) to achieve legitimacy, regardless of the efficacy and effectiveness of those practices. They function as power myths that are often ceremonially adopted. Legitimization derives from public policy and opinion, knowledge of education systems, social prestige, laws and definitions used in courts concerning negligence and prudence. Hence, elements of formal structure, embedded into bureaucracy, are manifestations of powerful institutional rules functioning as highly rationalized myths that influence organizations. The origins and development of formal organization are based upon the following assumptions: (a) the extent to which institutional rules arise in certain areas of activity, formal organizations are created and expanded by incorporating these rules as structural elements; (b) the more modernized the society, the more extensive the rationalized institutional structure in underlying areas and the higher the number of areas with rationalized institutions.

Scott and Meyer (1991) distinguish between technical and institutional environments. The first relates to efficiency and responses to market forces, while the institutional environment is focused on legitimacy and social environment. Addressing the impact of institutional environments on organizations, Meyer and Rowan (1977) assess three consequences: (a) the incorporation of external elements that are legitimate but not necessarily efficient; (b) the implementation of criteria for external or ceremonial assessment to set the value of structural elements (e.g. awards and external certifications); (c) how dependence on externally established institutions reduces turbulence and maintains stability (e.g. association and agreements relating to affiliation or state institutionalization, not to performance).

Following these lines, DiMaggio and Powell (1991) define the institutional field as organizations that constitute a recognized area of institutional life at the aggregate level, including suppliers, consumers, regulatory agencies and other organizations producing similar products or services. The contribution from this unit of analysis is the focus not only on competing organizations, but also on all relevant actors whose sources of power are not necessarily of an economic order. These authors observed that formal organizations, proposed by Meyer and Rowan (1977), are already established in modern society, and proposed that they continue to become more homogeneous as result of interaction processes, named isomorphisms, which occur in organizational fields and provide a context such that individual efforts to rationally deal with uncertainty and constraint lead to homogeneity in structure, culture and output. 
Organizations not only compete for resources and customers, but also for political power, institutional legitimacy, and social and economic adequacy. According to DiMaggio and Powell (1991), the process of institutional definition is composed of four parts: (a) an increase in the degree of interaction among organizations; (b) the emergence of precisely defined structures of domination and patterns of coalition; (c) an increase in the volume of information that organizations must address in the field; (d) development of a mutual awareness among participants in a group of organizations about their involvement in a common enterprise.

The concept of isomorphism is a powerful tool for understanding the politics and ceremony affecting the functioning of organizations. Three mechanisms are observed through which institutional isomorphic change occurs: (a) coercive isomorphism - from laws, political influence and the problem of legitimacy (a regulative ingredient of institution); (b) mimetic isomorphism - in which organizations imitate others, resulting in standard responses to uncertainty (a cultural-cognitive ingredient); (c) normative isomorphism - adoption of structures and patterns considered superior and associated with professionalization (a normative ingredient). Coercive isomorphism results from both formal and informal pressures exerted by organizations they are dependent upon as well as cultural expectations of the society in which the organization operates. These political influence pressures can be felt as force, persuasion, or even as invitations to collusion schemes (with the objective of evading the law) (DiMaggio \& Powell, 1991).

Not all institutional isomorphism derives from coercive authority. Uncertainty is also a relevant force that encourages imitation. Hence, organizations may be modeled on other organizations when technologies are not well understood, goals are ambiguous or when the environment creates uncertainty. Models can be diffused unintentionally through resignation and transfer of employees, or explicitly by organizations, such as consulting organizations or trade associations. The third mechanism of organizational change identified in DiMaggio and Powell (1991), normative isomorphism, comes primarily from pressures comprising formal education and a legitimation in a cognitive base, coming from academics as well as individuals who occupy distinguished positions in a range or organizations defining and promulgating rules and regulations about organizational and professional behavior.

Scott (2001) deepens the understanding of isomorphisms through the recovering of the philosophical and sociological bases of the institution construct. The author defines institutions as social structures having attained a high degree of resilience (resistance to shocks), including social norms, values, expectations, procedures, standards and routines. Three pillars are identified as constituents or supporting institutions: (a) regulatory pillar; (b) normative pillar; (c) cultural-cognitive pillar. The first pillar concerns the ability to establish rules, inspection of conformity and manipulation of sanctions (rewards and punishments) aiming to influence future behavior. These procedures can operate through informal mechanisms that may be diffuse or highly formalized to specialized players such as the police and courts.

In the normative pillar, emphasis is on normative rules that introduce a prescriptive dimension, which is evaluative and obligatory in social life. Normative systems include both values and norms. Values are conceptions of what is preferred or desirable with the construction of standards to which existing structures or behavior can be compared and evaluated. Norms concern how things should be done and define legitimate means to achieve certain purposes of value.

From the cultural-cognitive pillar, emphasis is on the following institutional elements: (a) the shared concepts that constitute the nature of social reality; (b) and the structures through which meaning is conceived. According to Scott (2001), in the cognitive paradigm what an individual does is largely a function of the internal representation of the world. Meanings arise from interaction, processed and maintained as they are used to assign significance to events. As the central Weberian premise, social action is considered to the extent the actor attaches meaning to the behavior, necessary not only for the profound understanding of objective conditions, but to their subjective interpretation as well. Along these lines, institutionalization is the central element in the perpetuation of social groups, as institutionalization implies the dissemination of similar meanings. The more institutionalized a conduct, the more predictable and controlled it becomes. In most cases, the conduct is carried out voluntarily 
through established institutional channels. Knowledge relative to society is a realization in the dual sense of the word, aimed to understand as well as to continuously reproduce the social reality. Institutionalization takes place when a reciprocal typification of habitual actions occurs by types of actors (Berger \& Luckmann, 1967). Hence, organizational structures (procedures, products, services, techniques, policies and programs) are institutionalized when they are believed to have some positive value for the organization, being so a causal strength for stable behavior patterns. It is worth noting that this definition of institutionalized structure leads to a contradiction in cultural terms with the definition of the institutionalized structure of Meyer and Rowan (1977), which is not related to effectiveness (Tolbert \& Zucker, 1996), thus posing an unanswered riddle in the neoinstitutionalism approach.

\section{Proposed Model of Heterogeneity of Isomorphic Pressures and Sustained Competitive Advantage}

Scott and Meyer (1994) observe a transition from technical to institutional, which is the most common approach in neoinstitutionalism literature. The rationale is that initial adoption of procedures is commonly due to technical reasons, while further adoptions are ceremonial adoptions driven by institutional motives from the followers. Oliver (1991) distinguishes among strategic responses that organizations generate from institutional pressures towards conformity. A fundamental contribution is the development of a preliminary conceptual framework for predicting different strategies. The author notes that, while the resource based view stresses a range of active choice behaviors to manipulate external dependencies and the allocation of critical resources, the institutional approach has tended to limit predictions to procedural environmental conformity. The author observes the overly passive and confirming depiction of the institutional approach, and the potential for diversity in the degree of choice, awareness, reactiveness, influence, and self-interest organizations display under institutional pressures.

In later work, Oliver (1997) applies institutional insights to the resource-based approach, proposing five main sources of organizational homogeneity: (a) regulatory pressures; (b) strategic alliances; (c) human capital transfer; (d) social and professional relationships; (e) blueprints of expertise. These features regarding organizational homogeneity arise from integration in social and economic relations. Such relationships are related to government, business partners, employees recruited from competitors, colleagues, business associations, consultants, and other sources of awareness of competitors' business practices.

On the other hand, Lawrence (1999) develops concepts related to institutional strategy applied to the description of organizational action patterns toward the management of institutional structures within which organizations compete for resources (reproduction or transformation of structures). The idea is that, while the processes by which organizations adopt institutionally-legitimated forms and practices have been examined in previous literature, little attention had been aimed at organizational work of sponsoring new practices and transforming existing institutions. Two types of institutional strategies are identified: (a) membership strategies that involve the definition of membership rules and meaning posed to a community; (b) standardized strategies aimed at the establishment of technical, legal and market compliance defining normal processes throughout the supply of a particular good or service.

Along these lines, Pache and Santos (2010) aimed to explain how organizations experience and respond to conflicting institutional demands. They advance on Oliver's (1991) model, which does not explore the conditions under which particular resources are mobilized, given the prediction of organizational resistance to multiple conflicting demands, and also advance on the rationale of organizational univocal decisions as portrayed in Kim, Shin, Oh and Jeong (2007). Returning to DiMaggio and Powell (1991) and Meyer and Rowan (1977), a fundamental premise of Pache and Santos (2010) is that, in a fragmented field, organizations are responsive to multiple uncoordinated constituents, increasing the odds that institutional expectations will compete between the logics of effectiveness and legitimacy. Based on Scott and Meyer (1991), Pache and Santos (2010) assume conflicting institutional pressures as a subset of institutional pressures, whose organizational responses include: (a) acquiescence 
(adoption of required arrangements by external institutional constituents); (b) compromise (partial conformity with all institutional expectations); (c) avoidance (circumvent conditions); (d) defiance (explicit rejection of at least one institutional demand); (e) manipulation (attempt to change the content of institutional requirements).

Recently, Ahmadjian and Yoshikawa (2013) observe a transition between two different types of institutional pressures, based on the recognition that even processes of organizational problem solving are subject to cognitive limits and political pressures (i.e. practice decoupling that do not fit technical needs; ceremonial or cursory adoption of practices). They observe that, when technical and institutional resolutions are taken into account, organizations solve internal problems and can also gain legitimacy from stakeholders, such as investors.

Barnett (2004) reflects that industry-wide cooperation from trade associations may significantly improve organizations' performance and survival rates, since strategies that trade associations employ to accomplish gains differ from the common concept of cooperation in the literature. Previous analysis had focused on ways organizations can increase technical capabilities by gaining access to other organizations' resources. However, trade associations differ in the sense that their objective is primarily to influence the external environment, rather than improve its members' internal capabilities. Thus, trade associations are a form of institutional strategy which, based on Lawrence (1999), are patterns of action that are concerned with managing institutional structures within which organizations compete for resources and trade association success is commonly determined by changes in external perceptions related to the sector. Barnett (2004) observed that trade associations allow organizations to more efficiently and effectively reason with resource holders to convince them to favor their sector, by being able to present a coherent front in a unified position. Based on DiMaggio (1988), these efforts critically shape institutional opinion and can be particularly critical for crisis recovery.

According to Lawrence and Suddaby (2006) and Lawrence, Suddaby and Leca (2011) on organizational research, even though traditional emphasis of institutional approaches has been on explanation of organizational similarity based on institutional conditions, a new emphasis emerges towards the understanding of the role actors have in effecting, transforming and maintaining institutions and fields. The authors analyze that institutional entrepreneurs are pivotal to institutional processes, given that new institutions arise when organized actors with sufficient resources identify in them opportunities to achieve highly valued objectives. However, the overall focus of institutional work has remained unarticulated. In their research, the authors adopt the premise of actors as rational in the context of being able to work with institutionally-defined logics of effect and adequacy and that, as such, culturally-defined forms of competence and knowledge are required, as well as creativity to adapt to demanding and dynamic conditions. It is suggested that the examination of institutional work is concerned with sets of practices in which institutional actors engage to maintain institutions as well as those associated with the creation of new institutions and the disruption of existing ones.

Along these lines, institutional structure is understood as both mutually constitutive of action and constituted by it (Giddens, 1984, 1986; Machado-da-Silva \& Coser, 2006; Orlikowski, 2000). Even in highly constrained environments, actors self-monitor, interpreting their actions in order to create sense of what they are doing, generating consciousness during the action, allowing the development of variations and the beginning of new institutionalizations processes, affecting the institutional structure. So institutional rules are not fixed or determined, but are rather a subject of ongoing formations and transformations by motivated actors.

Battilana, Leca and Boxenbaum (2009) state that institutional change is a complex process involving different types of forces and agents and that research should not only address how institutions influence actors' behavior, but also how these actors might influence and possibly transform institutions. Thus, the authors draw on the notion of institutional entrepreneurship as a new theme of research concerning endogenous explanations of institutional change. The authors identify the factors that enable the emergence of institutional entrepreneurship despite institutional pressures towards stability. Two categories of enabling conditions are identified: (a) field characteristics; (b) actors' social positions. Field characteristics can influence the potential of actors to become institutional entrepreneurs, but 
actors perceive field conditions differently depending on their social position, whose point of view yields differential access to resources. However, organizational heterogeneity is assumed to exist a priori and is considered a source of institutional entrepreneurship. Instead, we maintain the approach that organizational heterogeneity is not a cause, but a consequence of institutional entrepreneurship as will be detailed below in the presentation of our proposed theoretical model.

Beckert (2010a, 2010b) recognizes that Meyer and Rowan (1977), DiMaggio and Powell (1991) provide a one-sided focus that leaves out insights from other institutional and macro-sociological approaches and overlooks the role of divergent institutional development. Although the suggestion of divergent forces is not new, few attempts have been undertaken towards the integration of different theoretical premises of new sociological institutionalism. Drawing upon the typology proposed by DiMaggio and Powell (1991), Beckert (2010a, 2010b) demonstrates that the mechanisms identified by them as sources of isomorphic change can also support processes of divergent change.

Hence, a fundamental contribution from Beckert (2010a) concerns the proposal of a more integrated perspective on institutional development, based on the concept that, to understand the processes of institutional homogenization and heterogeneity, it is necessary to observe the mechanisms behind the processes through which institutional models prevalent in one social setting (i.e. nation or organizational field) might or might not emerge in another. Thus, contradictory theories concerning institutional change are not an issue of empirical failure but rather of theoretical deficiency.

Gawer and Phillips (2013) examine forms of institutional work organizations undertake externally in the processes that conduct change in the institutional logic that characterizes their field, as well as how they respond internally to such shifts. Respectively, two forms of institutional work carried out externally and internally are identified: (a) external practice work and legitimacy work; (b) internal practice work and identification work. In this sense, the actions of vesting, defining and advocacy are political work through which actors reconstruct the rules, property rights and boundaries that determine access to material resources, whereas constructing identities, changing norms and constructing networks are actions in which actors' belief systems are reconfigured. Finally, mimicry, theorizing and educating involve actions designed to change the abstract categorizations upon which meaning systems depend.

The ceremonial adoption has its basis in the appropriation by organizations of institutional resources in the field, regardless of efficacy and effectiveness (DiMaggio \& Powell, 1991; Meyer \& Rowan, 1977). We argue that when there is stability in the institutional field, organizations create and test variations of resources and capabilities based upon their idiosyncrasies, within the limits of the institutional conformity, aiming to differentiate themselves via efficacy and effectiveness in the technical dimension. This process, amplified by learning, leads to novelties in the field. Only in an ideal condition, strictly theoretical, it would be possible to consider a hermetic system in which the isomorphic pressure would imply perfectly equality between organizations. Simultaneously, as organizations become similar, the isomorphic pressure loses intensity, leading the system to its limit; meaning any additional demand can only be met by breaking the pattern, leading to pressure in the opposite direction, by differentiation. The exhaustion of the technical model by the emergence of technological, process, market or organizational-form innovations, originating in a company, an industry or even in a different industry, creates opportunity for review of the existing institutional framework in the field.

We argue that the legitimacy obtained through ceremonial adoption enables the institutional work of the organizations or groups of organizations that find new solutions based on idiosyncratic arrangements of resources for similar problems, and by the insertion of these organizations in the dominant coalition (Selznick, 1949, 1957) and conduction of institutionalization processes (Tolbert \& Zucker, 1996). These processes comprehend the participation in negotiations and decisions made in the sectorial associations and governmental organizations and/or development of deliberated strategies of dissemination of information. Along these lines, these organizations negotiate standards and rules to be followed (coercive isomorphism); create reputation and disseminate information that lead to the adoption of the arrangements of resources of their interest by other companies in uncertain situations in order to reduce risks involved in decision-making (mimetic isomorphism) (Bataglia, Silva, \& Klement, 2011); and disseminate information to be taught in the education of professionals in the institutional 
field, for example, by publishing technical manuals by standardization organizations like ISO (International Standardization Organization) (normative isomorphism).

There is thus an increase in isomorphic pressure, consequently, reinitiating a new cycle of ceremonial adoption in the institutional field that differentiates organizations belonging to the dominant coalition by the legitimation of the resource arrangement of their interest, associated with their effectiveness in the technical environment. Hence, we argue that this set of institutional work is highly related to obtaining the legitimacy organizations aspire to. Ultimately, legitimate organizations themselves define resources they should be allowed to acquire and employ in the institutional field. This process is verified in the study on the institutional and organizational genesis in the life sciences industry developed by Powell, Packalen and Whittington (2012) and is implicit in the field theory proposed by Fligstein and McAdam (2012). It could be the case that organizations that are part of trade associations and multinationals make up a significant amount of a nation's gross domestic product. These organizations are legitimate institutions by themselves and may heavily influence external environments rather than adopting externally imposed procedures.

Our argument expands the neoinstitutional theory and does not question its fundamentals. Ceremonial adoption remains central. The existing theory is strengthened from the focus "on how organizational actors are involved in cognitive processes of construction of reality" (Clegg, 1990, p. 83). Everyday relations between organizational actors in processes of competition, conflict, negotiation and exercise of power interfere in the definition and redefinition of the institutional structure and the existing isomorphisms (Bourdieu \& Wacquant, 1992; Jepperson, 1991), resulting in the construction of a negotiated environment (Bataglia, Franklin, Caldeira, \& Silva, 2009). Actors act in two ways, the first is the logic of compliance, targeting the best result given the current rules of the game, and in the second sense, trying to change the very rules of the game. The institutional structure is understood as mutually constitutive of action and constituted by it (Giddens, 1984, 1986; Machado-da-Silva \& Coser, 2006; Orlikowski, 2000).

It is worth noting that in the context of the application in organizations, the idiosyncrasy refers to peculiar characteristics of each organization with respect to its behavior. The behavior is inherent to its internal arrangement of resources aiming at managing its processes, systems, structures, people, and strategies, as well as inherent to its external activities concerning relations with suppliers, shareholders, financial agents, Government, trade unions, community and their customers.

These elements can be vectors that enable it to assume positions of leadership in situations that require changes in the status quo, in local terms (associations, trade unions, for example) or national and/or international terms when substantial changes are needed in the rules of the market game. These changes happens in the face of possible threats arising from modifications of regulatory legislation, insertion or modification of technologies, social movements, entry of new competitors or the insertion of product substitutes. Efficiently and effectively using this set of vectors that, in essence, are organizational assets, can result in a resource heterogeneity factor. With this heterogeneity, a particular organization can generate a competitive advantage from the point of view of its internal use, as well as its use in the external context, when it will be able to avail themselves of this differentiation of resources due to its idiosyncratic character in situations of potential threats to its market position.

Organizational idiosyncrasy is based on the history of the organization, its culture, values, reputation, brand, market power, lobbies (technological, commercial and political), size, skills, knowledge, allowing to the organization a differentiated positioning for problem solving in its field that could lead to an above-average level of profitability. Nonetheless, in a situation where part of this arrangement of resources is not considered an organizational strength, the organization could be in a situation of competitive parity or even competitive disadvantage. Thus, in the first situation, the organization is able to assume a leadership position and, therefore, be the main driver of changes in the existing institutional model. The second situation, in competitive parity, even though the organization may have some influence in decision-making relating to the existing institutional model, its strength in the process is less. 
Organizations that already are at a competitive disadvantage likely will be mere co-adjuncts of the decision-making process and in eventual changes to the existing institutional scenery. The first aforementioned organizations can participate with more intensity in the decisions that may alter the existing institutional scenery elements, in order to obtain advantages associated with changes. Although this intense participation, probably, should bring some loss to the other two types of companies, it is not always possible to predict that any advantages be a marked playing card. There are always risks involved, technological and geographical issues, for example.

The theory proposed is that, although organizations undergo pressures for aligning with their respective institutional environment, the manner in which organizations react and transform such pressures into favorable institutional environments - at first by complying ceremonially and, ultimately, by influencing and taking strategically institutionalization procedures for new idiosyncratic arranges of resources - properly integrates the resource-based and neoinstitutional frameworks into the organizational strategic field. Given the relevance of institutions in determining success or failure of specific strategies, it is essential to any organizational strategy to consider ways to influence the creation and maintenance of favorable institutions through institutional work.

Even though other authors have recognized the role of institutions for maintenance of strategic positions (Busanelo \& Vieira, 2007; Ingram \& Silverman, 2002; Queiroz, Vasconcelos, \& Goldszmidt, 2007; Silva, 2007; Song \& Cho, 1997; Tolbert \& Zucker, 1999), the means by which institutional resources could be obtained and employed for sustainable competitive advantage remained unclear through the available theoretical resource-based view and neoinstitutional theoretical framework. The model proposed expresses that, while some companies incorporate the demands of the institutional environment more effectively than others, organizations maintain and expand their competitive advantage when responses to institutional pressures are not reproduced as quickly or as effectively by other organizations. Since the institutional isomorphism promotes the survival and success of the organization, we consider it as a necessary process for maintaining a competitive advantage, causing a chain reaction of organizations wishing to maintain their competitiveness in their organizational field.

Institutionalized practices become VRIN due to the organization's ability to exploit resources at a wider level, as well as because of path dependency and their social complexity. Based on Meyer and Rowan (1977), organizations that incorporate socially-legitimized rationalized elements in their formal structures maximize their legitimacy and increase their capabilities as well as resources for survival. Hence, organizations incorporate institutional elements in a manner that is not necessarily uniform. To acquire and maintain sustained competitive advantage, the possession of resources and their idiosyncratic development is required, allowing organizations to achieve different strategic orientations with the same set of resources. The proposed model is illustrated in Figure 1. 


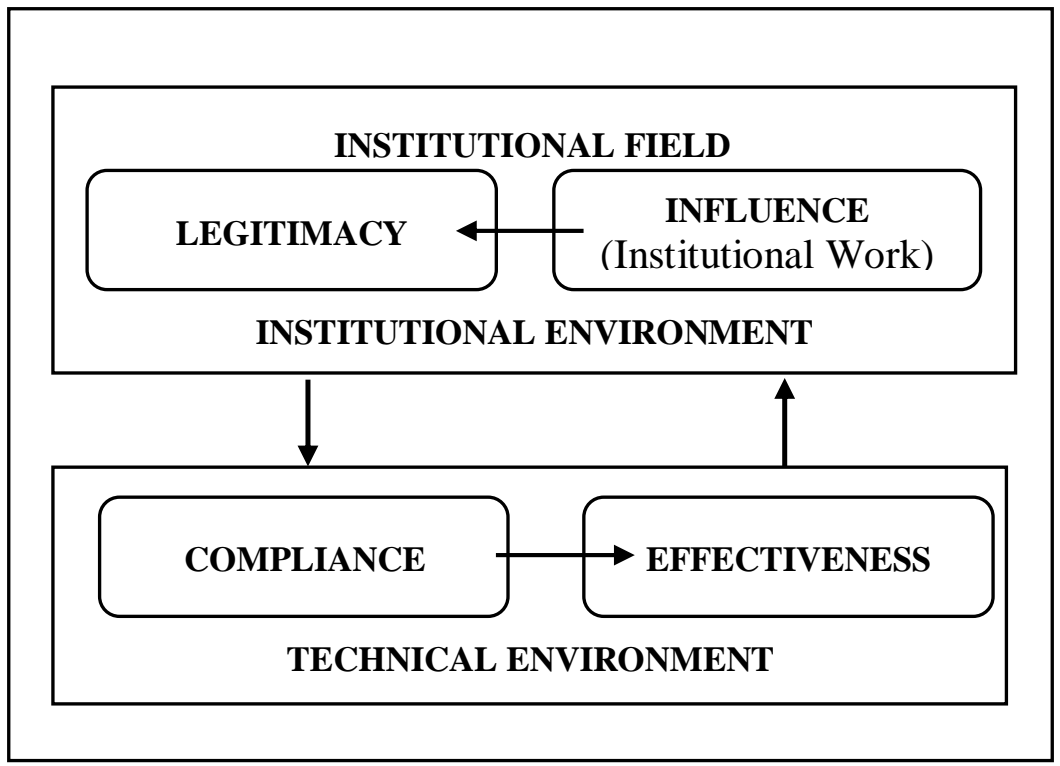

Figure 1. Model of Organizational Response to Isomorphic Pressures.

Source: Elaborated by the authors.

Adopting a perspective in organizational strategy integrating both the economic framework of the resource-based view and the neoinstitutional sociological approach, determinants of sustained competitive advantage includes compliance, effectiveness, influence and legitimacy. Compliance is the organizational adequacy to the institutional environment, incorporating socially rationalized procedures (myths) to obtain legitimacy such as services, techniques, policies and programs. Although the incorporation of rationalized elements does not necessarily imply efficiency, the organization should maximize their payoffs in relation to its competitors, transforming parameters of change into relative operational effectiveness, promoting the incorporation of myths that function to the benefit of the organization, differing from organizations that simply ceremonially adopt procedures. Ceremonialism implies conformity, characterized in this investigation as the first stage for organizational heterogeneity.

Aligned with Oliver (1991), we observe the theoretical potential of aligning the survival value of conformity with the adaptation to environmental uncertainty by actively managing or controlling resource flows, comprising manipulation of external dependencies and influence over the allocation of critical resources through the creation of variations of idiosyncratic arrangement of resources in order to get efficacy and effectiveness in the technical dimension, while maintaining compliance with institutional demands. Through socially complex resources, such as culture and reputation with suppliers and customers, as well as formal and informal relationships with other organizations, associations and other political bodies, influence through institutional work is an essential proactive tool for institutional changes and consequent power for favorable re-configuration of the institutional matrix, incorporating new arrangements of resources of interest. Characterized as a component that increases resource capacity and organizational survival, legitimacy is not itself a VRIN resource, but it follows influence, which means that the organization has a genuine ability to not only receive external pressures, but also to create myths, allowing greater flexibility of operation and establishment of ex-ante and ex-post limits to competition. The organization uses its institutional resources to differentiate itself and promote the mobilization of stakeholders for strategic processes. Complementing Pache and Santos (2010), we argue that these parameters increase the possibility for an organization to cope with seemingly conflicting demands.

As described by the resource-based view, institutions as non-tradable resources are applied in the resource framework, and are characterized as bodies of knowledge subsequently legitimized by typification of specific actors' actions. We observe that institutions are a superior resource in limited supply and, considering the apparent homogeneity of intra-organizational efficiency, an organization is led to abnormal returns due to its institutional heterogeneity. Applying to concepts in Berger and Luckmann (1967), legitimacy is not necessary in the first stage of institutionalization, since institution 
is simply a fact that does not require any new support, intersubjectively or biographically. The problem arises when the objectifications of institutional order need to be transmitted to a new generation. Thus, having broken down the unity of history and biography in order to restore it intelligently, explanations of and justifications for the salient elements in institutional tradition become necessary. Otherwise, competitive advantage becomes temporary and dissipates at the influence-level for not concreting itself into legitimacy.

Thus, legitimacy is the process of explanation and justification for the perpetuation of institutionalization. Legitimacy not only tells the individual they must perform an action in lieu of another, but also the motives for why things are done a certain way. In other words, knowledge - which, in reality, are the very institutions - precedes the values in the institutional legitimacy and, institutionalized, provides organizations competitive advantage. Prior to the proposed integrative model, a theoretical dissociation had been verified between institutions and resource capital. The fundamental implication is that the ability of organizations to generate rents from resources depends primarily on the organization's effectiveness in managing these resources' and capabilities' social context. Previous works in the strategic field generally maintained that institutional pressures were direct sources of organizational homogeneity, paradoxically assuming that relations of influence (e.g. government, business partners, employers recruited from competitors) could reduce homogeneity through the learning of business practices adopted by the competition.

Using the assumptions from the resource-based approach that lasting differences of profitability cannot be attributed only to industry differences and, even though most resources can be sold in imperfect markets of strategic factors, some non-tradable and immobile assets accumulated internally and related to the organization can be sources of competitive advantage. Thus, this paper places institutional resources in the same framework as capital resources for organizational heterogeneity, as VRIN (valuable, rare, imperfectly imitable, non-replaceable), non-tradable, immobile or imperfectly immobile resources.

\section{Implications and Concluding Remarks}

From the analysis of seminal authors and theoretical extensions, we have incorporated institutional resources and the environment through the resource-based view framework and neoinstitutionalism in organizational analysis.

An apparent theoretical contribution of this work to the neoinstitucional theory is that it proposes a solution to the riddle of the "contradiction in cultural understanding (i.e. structures mean commitment to action; and that structures may not be related to action)" (Tolbert \& Zucker, 1996, p. 180). In the theory proposed, ceremonial adoption is understood as effective and necessary by the organizational actors for their participation in the dominant coalition, making the institutional work that defines and redefines the institutional matrix feasible, allowing them to legitimize the arrangement of resources linked to the their effectiveness, differentiating them, creating heterogeneity. Therefore, ceremonially adopted institutional structures are a result of agents' actions. Thus, there would be no unlinked institutional structures of action per the criticism formulated (but not yet solved) by Giddens (1979), Geertz (1973), Goffman (1959), Granovetter (1985), Oliver (1991), Barley and Tolbert (1988) and Tolbert and Zucker (1996), among others.

Another apparent contribution is the focus shift from the macro dynamics of the institutional field to the relationship between the institutional structure and organizational actors' cognitive and agency processes via strategic decisions and political actions (Beckert, 2010a, 2010b; Campbell, 2004; Streeck \& Thellen, 2005).

Regarding the contribution to organization management, it is worth highlighting that for establishing organizational heterogeneity and sustained competitive advantage, the elements regarding 
the idiosyncratic application of institutional resources in response to isomorphic pressures comprise both the technical and institutional environments. Institutional resources are considered as VRIN and can be applied to the influence of key stakeholders such as partners and strategic competitors, governments, non-governmental organizations (NGOs) in support of organizational business strategy. This means negotiation of conflicts with major customers and suppliers, completion of acquisitions and alliances, as well as the assurance of funding from investors and banks. The conversation between the institutional and resource-based approaches suggests the elevation of the resource-based theory to the societal and organizational field level, rather than subsuming the latter into the first.

From the integrative model developed, managers take institutional pressures and opportunities to establish sustainable competitive advantage. This is only the first stage of response to institutional pressures, which is the compliance of minimum requirements to participate in the institutional game. The institutional isomorphism promotes the survival and success of the organization and consists of a necessary process for the maintenance of competitive advantage, causing a chain reaction often initiated by a leader organization(s) in an industry. This study highlights that managers need to be aware that the translation of institutional environmental pressures into greater organizational effectiveness, environmental impact and, ultimately, legitimacy of their actions will depend on the organization itself.

While some companies incorporate demands from the institutional environment more effectively than others - not just by possession, but by mobilization of strategic resources - organizations maintain or even expand their competitive advantage when their responses to institutional pressures are not reproduced as quickly or effectively by other organizations (idiosyncratic deployment). Among theoretical developments in organizational strategy, it appears that the institutional isomorphism provides opportunities for organizational heterogeneity, since the ceremonial adoption of procedures does not automatically translate into compliance, effectiveness, influence and legitimacy towards the strategy of maintenance and expansion of organizational competitiveness.

In addition, it should be noted that organizations must mobilize institutional resources such as knowledge, social-cognitive skills, and typifications of actions to achieve objectives of differentiation and competitive advantage. Legitimacy is not necessary in the first stage of institutionalization in which an institution is simply a fact that does not require any new support. However, for knowledge and actions to be intelligently assimilated by stakeholders, explanations of the salient elements of institutional tradition become necessary. As such typifications are justified, the legitimacy phenomenon occurs, which explains the institutional order granting validity to their cognitive and normative meanings, which is not solely a matter of values, but knowledge in its objective sense.

Thus, the institution remains at the organization for long-term use and is a source of competitive advantage. Institutions have characteristics of heterogeneity, limited imitation, and imperfect mobility. Thus, legitimacy is not a feature under the resource-based framework, but occurs from the justification of typified actions and values that shape institutions, which, in turn, are the result of idiosyncratic deployment of institutional resources that can be used as VRIN resources for the influence of stakeholders. Institutionalization is considered a reciprocal typification of actions, including the development of coalitions to influence legislators, working with institutional shareholders and also the influence of opinion formers in the media and analyst communities. Through negotiation, development of coalitions and public relations, business environments can be positively shaped, contributing to the heterogeneity of organizations and sustainable competitive advantage.

Research questions that emerge from the integrative model include the systematic assessment of institutional organizational resources, the understanding of the ways to achieve greater diversity from institutional pressures as well as practical ways to employ institutional resources to achieve greater organizational heterogeneity and sustained competitive advantage. Prior to the development of this integrative model, just through Oliver's (1997) classic integrative work, it was not possible to explain institutional resources in the theoretical framework of capital resources; questions about the management of institutional resources for generation of rent; ways to mobilize institutional resources in order to establish competitive advantage, which were previously considered sources of organizational heterogeneity mitigation and differences in rents. Thus, in our proposed integrative model, the 
incorporation of institutions as resources in a more specific and systematic manner in the theoretical framework of the resource-based approach is an important theoretical and practical contribution.

\section{References}

Ahmadjian, C., \& Yoshikawa, T. (2013). Killing two birds with one stone: board reforms in the Japanese electronics industry [Working Paper $\mathrm{n}^{\circ}$ 315]. Center on Japanese Economy and Business, Columbia Business School, New York, USA. Retrieved from http://academiccommons.columbia.edu/download/fedora_content/download/ac:158327/CONTE NT/WP_315.pdf

Azevedo, J. (2002). Updating organizational epistemology. In J. A. C. Baum (Ed.), The Blackwell companion to organizations (pp. 715-732). Malden, MA: Blackwell Publishers.

Barley, S. R., \& Tolbert, P. S. (1988). Institutionalization as structuration: methods and analytic strategies for studying links between structure and action. Proceedings of the conference on Longitudinal Field Research Methods for Studying Organizational Processes, Austin, Texas.

Barnett, M. L. (2004). How much does industry strategy matter? Organizational field dynamics and cooperation among rivals. Retrieved from http://dx.doi.org/10.2139/ssrn.624123

Barney, J. B. (1986). Strategic factor markets: expectations, luck and business strategy. Management Science, 32(10), 1231-1241. doi: 10.1287/mnsc.32.10.1231

Barney, J. B. (1991). Firm resources and sustained competitive advantage. Journal of Management, 17(1), 99-120. doi: 10.1177/014920639101700108

Basso, L. F. C., Meirelles, D. S., \& Pace, E. S. U. (2005, dezembro). The contributions of firm's productive assets to its competitive performance: a resource-based view approach in the software sector. Anais do Encontro Nacional de Economia, Natal, RN, Brasil, 33.

Bataglia, W., Franklin, M., Caldeira, A., \& Silva, A. A. (2009). Implicações das teorias ambientais para a administração estratégica. Revista Gestão.Org, 7(3), 314-330. Retrieved from http://www.revista.ufpe.br/gestaoorg/index.php/gestao/article/view/5/2

Bataglia, W., Silva, A. A., \& Klement, C. F. F. (2011). Dimensões da imitação entre empresas: um estudo na indústria de transformação brasileira. Revista de Administração Empresas, 51(2), 160174.

Battilana, J., Leca, B., \& Boxenbaum, E. (2009). How actors change institutions: towards a theory of institutional entrepreneurship. The Academy of Management Proceedings, 3(1), 65-107. doi: 10.1080/19416520903053598.

Beckert, J. (2010a). How do fields change? The interrelations of institutions, networks, and cognition in the dynamics of markets. Organization Studies, 31(5), 605-627. doi: $10.1177 / 0170840610372184$

Beckert, J. (2010b). Institutional isomorphism revisited: convergence and divergence in institutional change. Sociological Theory, 28(2), 150-166. doi: 10.1111/j.1467-9558.2010.01369.x

Berger, P., \& Luckmann, T. (1967). The social construction of reality: a treatise in the sociology of knowledge. New York, NY: Anchor Books.

Bourdieu, P., \& Wacquant, L. J. D. (1992). An invitation to reflexive sociology. Chicago: University of Chicago Press. 
Burns, T., \& Stalker, G. M. (1961). The management of innovation. London: Tavistock.

Busanelo, E. C., \& Vieira, S. F. (2007, setembro). Legitimando o processo estratégico: a efetividade de sua adoção. Anais do Congresso Internacional de Administração: Gestão Estratégica para o Desenvolvimento Sustentável, Ponta Grossa, PR, Brasil, 20.

Campbell, J. L. (2004). Institutional change and globalization. Princeton: Princeton University Press.

Caves, R., \& Porter, M. (1977). From entry barriers to mobility barriers: conjectural decisions and contrived deterrence to new competition. Quarterly Journal of Economics, 91(2), 241-262.

Clegg, S. (1990). Modern organization. London: Sage.

Cooney, K. (2007). Fields, organizations, and agency: toward a multilevel theory of institutionalization in action. Administration \& Society, 39(6), 687-718. doi: 10.1177/0095399707304116

Delbridge, R., \& Edwards, T. (2013). Inhabiting institutions: critical realist refinements to understanding institutional complexity and change. Organization Studies, 34(7), 927-947. doi: 10.1177/0170840613483805

Dierickx, I., \& Cool, K. (1989). Asset stock accumulation and sustainability of competitive advantage. Management Science, 35(12), 1504-1511. doi: 10.1287/mnsc.35.12.1504

DiMaggio, P. J. (1988). Interest and agency in institutional theory. In L. Zucker (Ed.), Institutional patterns and organizations (pp. 3-22). Cambridge, MA: Ballinger.

DiMaggio, P. J., \& Powell, W. W. (1983). The iron cage revisited: institutional isomorphism and collective rationality in organizational fields. American Sociological Review, 48(2), 147-160.

DiMaggio, P. J., \& Powell, W. (1991). The iron cage revisited: institutional isomorphism and collective rationality in organizational fields. In W. Powell \& P. J. DiMaggio (Orgs.), The new institutionalism in organizational analysis (pp. 63-82). Chicago: University of Chicago Press.

Feldman, M. S., \& Pentland, B. T. (2003). Reconceptualizing organizational routines as a source of flexibility and change. Administrative Science Quarterly, 48(1), 94-118. doi: 10.2307/3556620

Fligstein, N., \& McAdam, D. (2012). A theory of fields. New York, NY: Oxford University Press.

Gawer, A., \& Phillips, N. (2013). Institutional work as logics shift: the case of Intel's transformation to platform leader. Organization Studies, 34(8), 1035-1071. doi: 10.1177/0170840613492071

Giddens, A. (1979). Central problems in social theory: action, structure and contradiction in social analysis. Berkeley: University of California Press.

Giddens, A. (1984). The constitution of society: outline of the theory of structuration. Berkeley, CA: University of California Press.

Giddens, A. (1986). Action, subjectivity and the construction of meaning. Social Research, 53(3), 529545.

Ginsberg, A. (1990). Connecting diversification to performance: a sociocognitive approach. Academy of Management Review, 15(3), 514-535. doi: 10.5465/AMR.1990.4309115

Geertz, C. (1973). The interpretation of cultures. New York: Basic.

Goffman, E. (1959). The presentation of self in everyday life. Garden City: Doubleday Anchor Books.

Granovetter, M. (1985). Economic action and social structure: the problem of embeddedness. American Journal of Sociology, 91(3), 481-510. 
Hamel, G., \& Prahalad, C. K. (1994). Competing for the future. Boston: Harvard Business School Press.

Hannan, M. T., \& Freeman, J. (1977). Population ecology of organizations. American Journal of Sociology, 82(5), 929-64.

Holmes, R. M., Jr., Miller, T., Hitt, M. A., \& Salmador, M. P. (2013). The interrelationships among informal institutions, formal institutions, and inward foreign direct investment. Journal of Management, 39(2), 531-566. doi: 10.1177/0149206310393503

Ingram, P., \& Silverman, B. S. (2002). The new institutionalism in strategic management. Oxford. UK: $\mathrm{JAI} /$ Elsevier.

Jepperson, R. (1991). Institutions, institutional effects, and institutionalism. In P. DiMaggio \& W. Powell (Eds.), The new institutionalism in organizational analysis (pp. 143-163). Chicago: University of Chicago Press.

Kim, T. Y., Shin, D., Oh, H., \& Jeong, Y. C. (2007). Inside the iron cage: organizational political dynamics and institutional changes in presidential selection systems in Korean universities, 19852002. Administrative Science Quarterly, 52(2), 286-323. doi: 10.2189/asqu.52.2.286

Lawrence, T. B. (1999). Institutional strategy. Journal of Management, 25(2), 161-187. doi: $10.1177 / 014920639902500203$

Lawrence, T. B., \& Suddaby, R. (2006). Institutions and institutional work. In S. Clegg, C. Hardy, T. B. Lawrence, \& W. R. Nord (Eds.), The SAGE handbook of organization studies (2nd ed., pp. 215254). London: Sage.

Lawrence, T. B., Suddaby, R., \& Leca, B. (2011). Institutional work: refocusing institutional studies of organization. Journal of Management Inquiry, 20(1), 52-58. doi: 10.1177/1056492610387222

Lippman, S. A., \& Rumelt, R. P. (1982). Uncertain imitability. Bell Journal of Economics, 13(2), 418438. doi: $10.1057 / 9781137294678.0712$

Machado-da-Silva, C. L., \& Coser, C. (2006). Rede de relações interorganizacionais no campo organizacional de Videira-SC. Revista de Administração Contemporânea, 10(4), 9-45. doi: $10.1590 /$ S1415-65552006000400002

Meyer, J., \& Rowan, B. (1977). Institutionalized organizations: formal structure as myth and ceremony. American Journal of Sociology, 83(2), 340-363.

Mintzberg, H. (2003). Criando organizações eficazes (2a ed.). São Paulo: Atlas.

Nee, V. (2005). The new institutionalisms in economics and sociology. In N. J. Smelser \& R. Swedberg (Eds.), The handbook of economic sociology (pp. 49-74). Princeton, NJ: Princeton University Press.

Nelson, R. R., \& Winter, S. G. (1982). An evolutionary theory of economic change. Cambridge: Harvard University Press.

North, D. C. (1992). Institutions and economic theory. American Economist, 36(1), 3-6.

Oliver, C. (1991). Strategic responses to institutional processes. Academy of Management Review, 16(1), 145-179. doi: 10.5465/AMR.1991.4279002

Oliver, C. (1997). Sustainable competitive advantage: combining institutional and resource-based views. Strategic Management Journal, 18(9), 679-713. doi: 10.1002/(SICI)10970266(199710)18:9<697::AID-SMJ909>3.0.CO;2-C 
Orlikowski, W. J. (2000). Using technology and constituting structures: a practice lens for studying technology in organizations. Science, 11(4), 404-428. doi: 10.1287/orsc.11.4.404.14600

Pache, A. C., \& Santos, F. (2010). When worlds collide: the internal dynamics of organizational responses to conflicting institutional demands. Academy of Management Review, 35(3), 455-476.

Penrose, E. (1959). The theory of the growth of the firm. Oxford: Basil Blackwell.

Peteraf, M. A. (1993). The cornerstones of competitive advantage: a resource-based view. Strategic Management Journal, 14(3), 179-191. doi: 10.1002/smj.4250140303

Pfeffer, J., \& Salancik, G. R. (1978). The external control of organizations: a resource dependence perspective. New York, NY: Harper and Row.

Porter, M. E. (1980). Competitive strategy. New York: Free Press.

Powell, W. W., Packalen, K., \& Whittington, K. (2012). Organizational and institutional genesis: the emergence of high-tech clusters in the life sciences. In J. Padgett \& W. W. Powell (Eds.), The emergence of organization and markets (pp. 434-465). Princeton: Princeton University Press.

Queiroz, M., Vasconcelos, F., \& Goldszmidt, R. (2007). Economic rents and legitimacy: incorporating elements of organizational analysis institutional theory to the field of business strategy. Brazilian Administration Review, 4(1), 51-65. Retrieved from http://www.scielo.br/pdf/bar/v4n1/v4n1a05.pdf. doi: 10.1590/S1807-76922007000100005

Rumelt, R. P. (1984). Towards a strategic theory of the firm. In R. Lamb (Ed.), Competitive strategic management (pp. 556-570). Englewood Cliffs, NJ: Prentice-Hall.

Scott, W. R. (2001). Institutions and organizations (2nd ed.). Sage Publications.

Scott, W. R., \& Meyer, J. W. (1991). The organization of societal sectors: propositions and early evidence. In W. W. Powell \& P. DiMaggio (Eds.), The new institutionalism in organizational analysis (pp. 108-140). Chicago: University of Chicago Press.

Scott, W. R., \& Meyer, J. W. (1994). The rise of training programs in firms and agencies: an institutional perspective. In W. R. Scott \& J. W. Meyer (Eds.), Institutional environments and organizations: structural complexity and individualism (pp. 228-254). Thousand Oaks, CA: Sage Publications.

Selznick, P. (1949). TVA and the grass roots; a study in the sociology of formal organization. Berkeley, CA: University of California Press.

Selznick, P. (1957). Leadership in administration: a sociological interpretation. Evanston, IL: Row Peterson.

Silva, J. A. (2007). Institucionalização de práticas organizacionais em instituições inovadoras (Dissertação de mestrado). Universidade do Vale do Rio dos Sinos, São Leopoldo, RS, Brasil.

Song, J., \& Cho, D. (1997). Diversification strategies and the formation of Korean big business groups (chaebols): resource-based view and institutional perspectives on the causes of diversification [Working Paper n ${ }^{\circ}$ 9]. APEC Study Center, Columbia University, New York, USA.

Streeck, W., \& Thelen, K. (2005). Introduction. In W. Streeck \& K. Thelen (Eds.), Beyond continuity (pp. 1-39). Oxford: Oxford University Press.

Tolbert, P. S., \& Zucker, L. G. (1996). The institutionalization of institutional theory. In S. Clegg \& W. R. Nord (Eds.), Handbook of organizational studies (pp. 169-184). London: Sage Publications. 
Tolbert, P. S., \& Zucker, L. G. (1999). A institucionalização da teoria institucional. In S. R. Clegg, C. Hardy, \& W. R. Nord (Eds.), Handbook de estudos organizacionais: modelos de análise e novas questões em estudos organizacionais (pp. 196-219). São Paulo: Atlas.

Wernerfelt, B. (1984). A resource-based view of the firm. Strategic Management Journal, 5(2), 171180. 